\title{
MEASURING THE EFFECTIVENESS OF A SIMPLIFIED COBIT-BASED IT PROCESS MATURITY ASSESSMENT METHOD
}

\author{
Budi Yuwono, Muhammad Nasri, and Rein Nusa Triputra \\ Faculty of Computer Science, Universitas Indonesia, Kampus Baru UI Depok, Jawa Barat, 16424, \\ Indonesia \\ E-mail: yuwono@cs.ui.ac.id
}

\begin{abstract}
We propose a simplified method for measuring the maturity levels of an organization's information technology (IT) processes that is based on IT Governance Institute's COBIT (Control Objectives for Information and Related Technology) framework. The method is designed for quickly assessing an organization's IT process maturity in situations where the availability of information for a more thorough assessment method is very limited. To investigate the accuracy of the proposed method, we evaluate the consistency between the result of the IT process maturity assessment of an organization and the conditions reported by the organization as impediment to the achievement of its IT goals. The underlying assumption is that a condition that is perceived by an organization as a problem will drive the organization to develop a process that can effectively deal with the condition. We show that there is good enough consistency to support the use of the proposed maturity assessment method.
\end{abstract}

Keywords: IT Governance, maturity assessment

\begin{abstract}
Abstrak
Kami mengusulkan sebuah metode sederhana untuk mengukur tingkat kematangan (maturity) dari proses teknologi informasi (TI) suatu organisasi yang didasarkan pada IT Governance Institute's COBIT framework (Control Objectives for Information and Related Technology). Metode ini dirancang untuk melakukan penilaian dengan cepat dari tingkat kematangan proses TI suatu organisasi dalam situasi di mana ketersediaan informasi untuk metode penilaian yang lebih menyeluruh sangat terbatas. Untuk mengetahui ketepatan metode yang diusulkan, kami mengevaluasi konsistensi antara hasil penilaian kematangan proses TI dari suatu organisasi dan kondisi yang dilaporkan oleh organisasi sebagai rintangan bagi tercapainya tujuan IT. Asumsi yang mendasarinya adalah bahwa suatu kondisi yang dirasakan oleh organisasi sebagai masalah akan mendorong organisasi untuk mengembangkan sebuah proses yang dapat secara efektif menangani kondisi tersebut. Kami menunjukkan bahwa ada konsistensi yang cukup baik untuk mendukung penggunaan metode penilaian kematangan yang diusulkan.
\end{abstract}

Kata Kunci: tata kelola TI, maturity assessment

\section{Introduction}

This research is aimed at measuring the effectiveness of a simplified information technology (IT) process maturity assessment method by comparing the result of the maturity assessment of an organization's IT processes with the actual problems faced by the organization that are supposed to be solved by the IT processes. The problems that we investigate are pertinent to the execution of the organization's IT plan. This approach is based on an assumption that an organization will put in place a control mechanism to deal with a condition perceived by the organization as a problem. The more concerned an organization about a problem the more mature its process that embeds a control mechanism to deal with the problem.

IT Plan Execution. IT planning is among the top ten essential processes that constitute the minimum baseline for optimal IT governance [1]. This process is one of the core processes for ensuring that business' strategic and tactical plans are aligned with IT strategies and tactical plans, and vice versa. For an organization to be effective in governing its IT, it must have a plan that serves as guidance to various IT-related decisions that the organization must take. The IT plan should lay out the strategic direction for the development, the architectural blueprint, and the implementation roadmap of the organization's IT. However, having an IT plan is just one part of the journey toward aligning IT with business, another part that is more challenging is executing the plan 
successfully. Executing an IT plan involves making decisions about resource allocation, risk assessment and mitigation, and organizational change, among other things.

In this research we collect data about the unfavorable conditions that are perceived as impediment by an organization in executing its IT plan. Ideally, most of such unfavorable conditions can be dealt with using IT governance control mechanisms. Such controls are typically embedded within organization's IT processes such as planning \& organization, acquiring \& implementation, delivery \& support, and monitoring \& evaluation processes [2]. We assume that the degree of effectiveness of such controls correlates with the organization's level of awareness of the impeding conditions.

This research was conducted through case studies at two government institutions at the level of directorate general (one level below ministry/state-department) within the government of Republic of Indonesia. Because we were requested not to disclose the names of the organizations, we will call them Organization-A and Organization-B. Each of the IT plans was developed through a number of stakeholders meeting sessions to assure that the plan has been given collective approval and support by the stakeholders of the organization. Unfavorable conditions that are perceived as impediments to the execution of IT plan were identified from statements elicited through interviews with the head of IT division at each of the organizations. The respondents were asked with the following question: Based on your organization's experience up until now, were there any problems faced by your organization in executing its IT plans? If yes, what were they? We then extracted the issue statements from the answers and summarized statements that represent the same issue.

Maturity Assessment. According to the Information Technology Governance Institute (ITGI), IT governance is the responsibility of executives and the board of directors, and consists of the leadership, organizational structures and processes that ensure that the enterprise's IT sustains and extends the organization's strategy and objectives [3]. As the governance of IT typically covers a broad scope of activities, it can be helpful to conceptualize the application of IT governance to an organization's day-to-day activities in terms of business processes. Three of the most prominent process frameworks, according to Betz [4], are the Capability Maturity Model Integration or CMMI [5], the ITGI's Control Objectives for Information and related Technology or COBIT [2], and the OGC's Information Technology Infrastructure Library or
ITIL. These frameworks include some sort of capability maturity model components [6].

\section{Methodology}

The central concept behind a maturity model is the notion that it is possible to evaluate the maturity of various processes based on a hierarchical scale. Although numerous maturity models exist, what they have in common is the idea that it is possible to view organizational development as a continuum of stages that organizations pass through as their processes go from immaturity to maturity [7]. Despite minor differences in terminology, all models begin with a Level Zero (process nonexistent) or Level One (initial process), continuing on with Level Two (repeatable process), Level Three (defined process), Level Four (managed process), and Level Five (optimized process). De Haes and Van Grembergen see the value of a maturity model as a tool that offers an easy-to-understand way to determine the as is and to be positions and enables the organization to benchmark itself against best practices and standard guidelines. In this way, gaps can be identified and specific actions can be defined to move toward the desired level of strategic alignment/governance maturity [8].

The COBIT framework focuses on process control in that it positions itself as a methodology that enables organizations to manage IT governance processes, and in particular, to conduct audits. COBIT is often characterized as a set of control objectives and management guidelines that organizations can apply to any of the 34 IT processes that the IT Governance Institute has identified [9]. In addition to the control objectives, CobiT also features critical success factors, as well as a six-level maturity model that organizations can use to implement IT governance functions. As stated in COBIT 4.1 documentation, determining what the desired state is for the maturity of any of the IT process areas (capability) depends primarily on the return on investment that an organization seeks.

In this research, we measure the maturity of an organization's IT governance controls embedded in IT processes using a simplified assessment method based on COBIT 4.1. The motivation behind the development of the simplified assessment method is that it is much easier for stakeholders in the organization to understand, and thus, it is much easier for the assessor and the organization's stakeholders to agree on the maturity level of the organization's IT processes. The maturity of each process in each of the four COBIT domains, i.e., Plan \& Organize (PO), Acquire \& Implement (AI), 
Deliver \& Support (DS), and Monitor \& Evaluate (ME), was scored using the standard CMM (the Software Engineering Institute's Capability Maturity Model)-based process maturity, ranging from 0 to 5. The proposed method uses a checklist that we developed based on the COBIT 4.1 process maturity model to rate the maturity of an IT process using the criteria as shown in table I.

To assess the maturity of an IT process, the following question-answer session is conducted with the respondent:

Step 1 : Describe the output of the process.

Step 2 : Ask whether such output has ever been produced by the organization. If none then the maturity level is 0 , otherwise go to step 3.

Step 3 : Ask when or how many times such output was produced by the organization. If not regularly (on every similar occasion) then the maturity level is 1 , otherwise go to step 4.

Step 4 : Ask how (what activities performed) the output is produced by the organization. If there is no formal policy or guideline as to when and how it is to be performed then the maturity level is 2 , otherwise go to step 5.

Step 5: Ask how the quality of the output or the effectiveness of the activities is measured by the organization. If there is no such measurement then the maturity level is 3 , otherwise go to step 6.

Step 6: Ask whether and how the activities that produce the output have been improved overtime. If there is no such improvement then the maturity level is 4 , otherwise go to step 7.

Step 7 : Assign the process' maturity level to 5.

In analyzing the links between the process maturity and the conditions perceived as impediment to the execution of IT plan, we use COBIT 4.1 mapping of the IT processes to organization IT goals. The underlying assumption is that the purported impeding conditions were stated in the context of some aspects in the organization's IT plan implementation, and such aspects can be stated as the organization's IT goals. The COBIT 4.1 IT goals to IT process mapping is as shown in table II.

Using the simplified checklist, we obtained the maturity levels of Organization-A and Organization-B's IT processes. Table III shows the maturity scores of both organizations' IT processes.

Organization-A and Organization-B are two government institutions under a state department/ministry of the government of Republic of Indonesia. Organization-A routinely processes a large amount of data sent by all state departments and other non-departmental government institutions in the country. Organization-B is the inspectorate general of the department/ministry. Organization-A has made use of IT extensively, and according to the current IT plan, the reliance on IT by the organization business processes will increase significantly. As for Organization-B, it has only recently started to employ organization-wide IT systems.

TABLE 1

CRITERIA FOR EACH IT PROCESS MATURITY LEVEL

\begin{tabular}{|c|c|c|}
\hline $\begin{array}{l}\text { Maturity } \\
\text { Level }\end{array}$ & Category & Criteria \\
\hline 0 & Non-existent & No such a process exists \\
\hline 1 & Ad hoc & $\begin{array}{l}\text { The process is performed incidentally without } \\
\text { any standard }\end{array}$ \\
\hline 2 & Repeatable & $\begin{array}{l}\text { The process is performed routinely but } \\
\text { undocumented }\end{array}$ \\
\hline 3 & Defined & $\begin{array}{l}\text { The process is performed routinely according to } \\
\text { some documented standard }\end{array}$ \\
\hline 4 & Managed & $\begin{array}{l}\text { The process is performed routinely according to } \\
\text { some documented standard and measured }\end{array}$ \\
\hline 5 & Optimized & $\begin{array}{l}\text { The process is performed routinely according to } \\
\text { some documented standard, measured, and } \\
\text { continuously improved }\end{array}$ \\
\hline
\end{tabular}


TABLE II

COBIT'S MAPPING BETWEEN IT GOALS AND IT PROCESSES

\begin{tabular}{|c|c|}
\hline$\overline{\mathrm{No}}$ & IT Goal \\
\hline 1 & $\begin{array}{l}\text { Respond to business } \\
\text { requirements in alignment with } \\
\text { the business strategy }\end{array}$ \\
\hline 2 & $\begin{array}{l}\text { Respond to governance } \\
\text { requirements in line with } \\
\text { board direction }\end{array}$ \\
\hline 3 & $\begin{array}{l}\text { Ensure satisfaction of end } \\
\text { users with service offerings } \\
\text { and service levels }\end{array}$ \\
\hline 4 & $\begin{array}{l}\text { Optimise the use of } \\
\text { information. }\end{array}$ \\
\hline 5 & Create IT agility. \\
\hline 6 & $\begin{array}{l}\text { Define how business } \\
\text { functional and control } \\
\text { requirements are translated in } \\
\text { effective and efficient } \\
\text { automated solutions. }\end{array}$ \\
\hline 7 & $\begin{array}{l}\text { Acquire and maintain } \\
\text { integrated and standardised } \\
\text { application systems }\end{array}$ \\
\hline 8 & $\begin{array}{l}\text { Acquire and maintain an } \\
\text { integrated and standardised IT } \\
\text { infrastructure }\end{array}$ \\
\hline 9 & $\begin{array}{l}\text { Acquire and maintain IT skills } \\
\text { that respond to the IT strategy. }\end{array}$ \\
\hline 10 & $\begin{array}{l}\text { Ensure mutual satisfaction of } \\
\text { third-party relationships. }\end{array}$ \\
\hline 11 & $\begin{array}{l}\text { Ensure seamless integration of } \\
\text { applications into business } \\
\text { processes. }\end{array}$ \\
\hline
\end{tabular}

12 Ensure transparency and understanding of IT cost, benefits, strategy, policies \& service levels

13 Ensure proper use and performance of the applications and technology solutions

14 Account for and protect all IT assets.

15 Optimise the IT infrastructure, resources and capabilities.

16 Reduce solution and service delivery defects and rework.

17 Protect the achievement of IT objectives.

18 Establish clarity of business impact of risks to IT objectives and resources

19 Ensure that critical and confidential information is withheld from those who should not have access to it.

20 Ensure that automated business transactions and information exchanges can be trusted.

21 Ensure that IT services and infrastructure can properly resist and recover from failures due to error, deliberate attack or disaster.

22 Ensure minimum business impact in the event of an IT service disruption or change.

$\mathrm{AI} 3, \mathrm{AI} 5$

PO 7, AI 5

DS2

$\mathrm{PO} 2, \mathrm{AI} 4, \mathrm{AI} 7$

PO 5, PO 6, DS 1, DS 2, DS 6, ME 1, ME 4

PO 6, AI 4, AI 7, DS 7, DS 8

PO 9, PO 9, DS 5, DS 9, DS12, ME 2 PO 3, AI 3, DS 3,

DS 7, DS 9

PO 8, AI 4, AI 6,

AI 7, DS10

PO 9, DS10, ME 2

PO9

PO 6, DS 5, DS11, DS12

PO 6, AI 7, DS 5

PO 6, AI 7, DS 4, DS 5, DS12, DS13, ME 2

PO 6, AI 6, DS 4, DS12

\begin{tabular}{|c|c|c|}
\hline No & IT Goal & $\begin{array}{c}\text { Supporting } \\
\text { Processes }\end{array}$ \\
\hline 23 & $\begin{array}{l}\text { Make sure that IT services are } \\
\text { available as required. }\end{array}$ & $\begin{array}{l}\text { DS 3, DS 4, DS 8, } \\
\text { DS13 }\end{array}$ \\
\hline 24 & $\begin{array}{l}\text { Improve IT's cost-efficiency } \\
\text { and its contribution to } \\
\text { business profitability. }\end{array}$ & PO 5, DS 6 \\
\hline 25 & $\begin{array}{l}\text { Deliver projects on time and } \\
\text { on budget, meeting quality } \\
\text { standards }\end{array}$ & PO 8, PO10 \\
\hline 26 & $\begin{array}{l}\text { Maintain the integrity of } \\
\text { information and processing } \\
\text { infrastructure }\end{array}$ & AI 6, DS 5 \\
\hline 27 & $\begin{array}{l}\text { Ensure IT compliance with } \\
\text { laws, regulations and } \\
\text { contracts. }\end{array}$ & $\begin{array}{l}\text { DS11, ME 2, ME } \\
3, \mathrm{ME} 4\end{array}$ \\
\hline 28 & $\begin{array}{l}\text { Ensure that IT demonstrates } \\
\text { cost-efficient service quality, } \\
\text { continuous improvement and } \\
\text { readiness for future change. }\end{array}$ & $\begin{array}{c}\text { PO 5, DS 6, ME 1, } \\
\text { ME } 4\end{array}$ \\
\hline
\end{tabular}

$\mathrm{PO} 3, \mathrm{AI} 3, \mathrm{AI} 5$

TABLE III

The MATURITY LeVEL SCORES OF ORGANIZATION-A AND

\section{ORGANIZATION-B'S IT PROCESSES}

\begin{tabular}{lcc}
\hline \multicolumn{1}{c}{ Process } & Maturity Level \\
& Org. A & Org. B \\
\hline PO 1 Define a Strategic IT Plan & 3 & 3 \\
PO 2 Define the Information Architecture & 3 & 3 \\
PO 3 Determine Technological Direction & 3 & 3 \\
PO 4 Define the IT Processes, & 3 & 3 \\
Organisation and Relationships & & \\
PO 5 Manage the IT Investment & 2 & 3 \\
PO 6 Communicate Management Aims & 2 & 2 \\
and Direction & & \\
PO 7 Manage IT Human Resources & 2 & 3 \\
PO 8 Manage Quality & 2 & 1 \\
PO 9 Assess and Manage IT Risks & 2 & 4 \\
PO10 Manage Projects & 2 & 3 \\
AI 1 Identify Automated Solutions & 2 & 3 \\
AI 2 Acquire and Maintain Application & 3 & 1 \\
Software & & \\
AI 3 Acquire and Maintain Technology & 3 & 2 \\
Infrastructure & & \\
AI 4 Enable Operation and Use & 3 & 3 \\
AI 5 Procure IT Resources & 3 & 2 \\
AI 6 Manage Changes & 2 & 1 \\
AI 7 Install and Accredit Solutions and & 3 & 1 \\
Changes & & \\
DS 1 Define and Manage Service Levels & 1 & 2 \\
DS 2 Manage Third-party Services & 1 & 1 \\
DS 3 Manage Performance and Capacity & 1 & 1 \\
DS 4 Ensure Continuous Service & 2 & 2 \\
DS 5 Ensure Systems Security & 2 & 2 \\
DS 6 Identify and Allocate Costs & 3 & 0 \\
DS 7 Educate and Train Users & 3 & 1 \\
DS 8 Manage Service Desk and Incidents & 2 & 2 \\
DS 9 Manage the Configuration & 2 & 2 \\
DS10 Manage Problems & 3 & 3 \\
DS11 Manage Data & 3 & 1 \\
DS12 Manage the Physical Environment & 2 & 1 \\
DS13 Manage Operations & 2 & 2 \\
ME 1 Monitor and Evaluate IT & 1 & 2 \\
Performance & & \\
ME 2 Monitor and Evaluate Internal & 1 & 2 \\
Control & & \\
ME 3 Ensure Compliance With External & 1 & 1 \\
Requirements & \\
ME 4 Provide IT Governance & & \\
\hline \hline & \\
\hline
\end{tabular}


TABLE IV

ISSUES THAT ARE PERCEIVED AS IMPEDIMENTS TO IT PLAN EXECUTION BY ORGANIZATION-A

\begin{tabular}{|c|c|c|}
\hline No & Issue & Case \\
\hline A-1 & $\begin{array}{l}\text { Not enough technical } \\
\text { skill and knowledge to } \\
\text { translate items in the IT } \\
\text { plan into technical } \\
\text { requirement. }\end{array}$ & $\begin{array}{l}\text { Acquired technology does } \\
\text { not fit with the business } \\
\text { need that drives the } \\
\text { acquisition due to } \\
\text { insufficient feasibility } \\
\text { analysis. }\end{array}$ \\
\hline A-2 & $\begin{array}{l}\text { Not enough skill and } \\
\text { knowledge to } \\
\text { effectively manage } \\
\text { relationship with } \\
\text { suppliers/contractors to } \\
\text { assure the delivery of } \\
\text { intended results. }\end{array}$ & $\begin{array}{l}\text { Many bad experiences with } \\
\text { suppliers/contractors lead } \\
\text { to organization's reluctance } \\
\text { in seeking external expert } \\
\text { assistance. }\end{array}$ \\
\hline A-3 & $\begin{array}{l}\text { Resistance of business } \\
\text { users to potential } \\
\text { changes in business } \\
\text { processes caused by the } \\
\text { implementation of new } \\
\text { IT systems. }\end{array}$ & $\begin{array}{l}\text { Business users are skeptical } \\
\text { about how their business } \\
\text { processes can be made } \\
\text { more efficient through the } \\
\text { use of IT. }\end{array}$ \\
\hline A-4 & $\begin{array}{l}\text { Changes in currency } \\
\text { exchange rate can } \\
\text { render the approved } \\
\text { budget insufficient to } \\
\text { achieve the } \\
\text { implementation target. }\end{array}$ & $\begin{array}{l}\text { Most equipment prices are } \\
\text { in US dollar. A proposed IT } \\
\text { budget item was approved } \\
\text { using an exchange rate } \\
\text { lower than the rate at the } \\
\text { time of the implementation. } \\
\text { As a result, the budget is no } \\
\text { longer enough to deliver } \\
\text { the target of the } \\
\text { implementation. }\end{array}$ \\
\hline A-5 & $\begin{array}{l}\text { Not enough skill and } \\
\text { experience in using IT } \\
\text { plan as a reference to } \\
\text { guide IT decisions. }\end{array}$ & $\begin{array}{l}\text { Different interpretations } \\
\text { about how and in what } \\
\text { priority ordering the IT } \\
\text { plan should be } \\
\text { implemented undermine } \\
\text { the unity of the } \\
\text { implementation efforts. }\end{array}$ \\
\hline
\end{tabular}

TABLE V

ISSUES THAT ARE PERCEIVED AS IMPEDIMENTS TO IT PLAN EXECUTION BY ORGANIZATION-A

\begin{tabular}{|c|c|c|}
\hline Issue & $\begin{array}{l}\text { IT } \\
\text { Goal }\end{array}$ & Needed Capability \\
\hline A-1 & 6 & $\begin{array}{l}\text { Translating business requirements into IT } \\
\text { capability }\end{array}$ \\
\hline A-2 & 9 & Managing suppliers/contractors \\
\hline A-3 & 13 & Educating end users \\
\hline A-4 & 24 & $\begin{array}{l}\text { Managing IT investment based on IT } \\
\text { contribution }\end{array}$ \\
\hline A-5 & 24 & $\begin{array}{l}\text { Understanding IT contribution to business } \\
\text { effectiveness }\end{array}$ \\
\hline B-1 & 9 & Managing suppliers/contractors \\
\hline B-2 & 9 & Selecting competent suppliers/contractors \\
\hline
\end{tabular}

Table IV lists the issues raised by the respondent at Organization-A regarding the execution of the organization's IT plan. Table V lists IT plan execution issues raised by Organization-B.

\section{Results and Analysis}

The IT plan execution issues can be said to impede the attainment of the organizations' certain IT goals. The relevant COBIT's IT goals that are affected by the issues are identified as shown in table VI.

By taking the average maturity level score of processes that support an IT goal, according to COBIT's IT processes to IT goals mapping, we obtained a score that represents each organization's capability of achieving the IT goals. Table VII shows the capability scores in attaining the IT goals of Organization-A and Organization-B, respectively. The scores for IT goals that are of interest with regard to the identified IT plan execution issues are marked with asterisks.

We compare the organizations' capability to attain the IT goals and the IT goals that are identified as having issues to analyze whether they are consistent. As shown in figure 1 and 2, an organization whose IT plan executions issues identified as impediments to the attainment of an IT goal has a capability score of 2.5 (repeatable toward defined according to some standard) or higher to achieve the goal, except for organization-A's goal no. 6 where the capability score is 2.33 . Both organizations have high scores in their capability to manage and procure suppliers/contractors (IT goal no. 9) and both organizations view that dealing with suppliers/contractors was an issue in the execution of their IT plans.

\section{Conclusion}

From the results of this study we can draw a conclusion - which cannot be generalized but, at least, applies to the organizations that we studied that for the organizations to overcome their issues in executing their IT plans they had to improve the maturity levels of the relevant IT processes higher than level 2 (repeatable). In the case IT goal no. 6 for organization-A, the average maturity level of IT processes relevant to achieving the goal is slightly lower than those of the other IT goals. This is due to the longer time required by the organization to train its staff in system analysis skills of which the organization is currently (as of this writing) lacking.

It can be stated that the results of the study has demonstrated the viability of the proposed simplified 
TABLE VI

THE SCORES OF ORGANIZATION-A AND ORGANIZATION-B'S

\begin{tabular}{rrrr}
\multicolumn{4}{c}{ CAPABILITY IN ACHIEVING THEIR IT GOALS } \\
\hline \hline IT Goal & $\begin{array}{c}\text { Num. of } \\
\text { Processes }\end{array}$ & \multicolumn{1}{c}{ Org-A } & \multicolumn{1}{c}{ Org-B } \\
\hline 1 & 10 & 1.90 & 2.20 \\
2 & 5 & 2.00 & 2.80 \\
3 & 8 & 2.13 & 1.88 \\
4 & 2 & 3.00 & 2.00 \\
5 & 4 & 2.25 & 2.75 \\
6 & 3 & $* 2.33$ & 1.67 \\
7 & 3 & 3.00 & 2.00 \\
8 & 2 & 3.00 & 2.00 \\
9 & 2 & $* 2.50$ & $* 2.50$ \\
10 & 1 & 1.00 & 1.00 \\
11 & 3 & 3.00 & 2.33 \\
12 & 7 & 1.57 & 1.86 \\
13 & 5 & $* 2.60$ & 1.80 \\
14 & 5 & 1.80 & 2.20 \\
15 & 5 & 2.40 & 1.80 \\
16 & 5 & 2.60 & 1.80 \\
17 & 3 & 2.00 & 3.00 \\
18 & 1 & 2.00 & 4.00 \\
19 & 4 & 2.25 & 1.50 \\
20 & 3 & 2.33 & 1.67 \\
21 & 6 & 2.00 & 1.57 \\
22 & 4 & 2.00 & 1.25 \\
23 & 4 & 1.75 & 1.50 \\
24 & 2 & $* 2.50$ & 1.50 \\
25 & 2 & 2.00 & 2.00 \\
26 & 2 & 2.00 & 1.50 \\
27 & 4 & 1.50 & 1.75 \\
28 & 4 & 1.75 & 2.00 \\
\hline \hline
\end{tabular}

IT process maturity assessment method, as it produced indications of an organization's control strengths that correspond with conditions that were perceived as problems by the organization.

In this study, we have not taken into consideration the interrelationships among IT goals. A further study is required to look into such interrelationships.

\section{Reference}

[1] W. Van Grembergen \& S. DeHaes, Enterprise Governance of Information Technology: Achieving Strategic Alignment and Value, Springer, New York, 2009.

[2] IT Governance Institute, CobiT 4.1: Control Objectives, Management Guidelines, Maturity Models, 2007.

[3] IT Governance Institute, Board Briefing on IT Governance, 2nd ed., 2003.

[4] C.T. Betz, Architecture and patterns for service management, resource planning, and governance: Making shoes for the cobbler's children, Morgan Kaufmann, San Francisco, 2007.

[5] Carnegie Mellon Software Engineering Institute, CMMI for Development, Version 1.2, CMU/SEI-2006-TR-008 ESC-TR-2006008, 2006.

[6] IT Service Management Forum, Aligning COBIT, ITIL, and ISO 17799 for Business Benefit: A Management Briefing from ITGI and $O G C$, IT Governance Institute, USA, 2005.

[7] G.P. Rogers, The Role of Maturity Models in IT Governance: A Comparison of the Major Models and Their Potential Benefits to the Enterprise in Information Technology Governance and Service Management: Frameworks and Adaptations, IGI Global, Hershey PA, 2009.

[8] S. DeHaes \& W. Van Grembergen, "IT Governance and Its Mechanisms," Information Systems Control Journal, 2004.

[9] M. Lankhorst et al., Enterprise Architecture at Work: Modelling, Communication, and Analysis, Springer, Berlin, 2005. 